УДК 94:323.15](477) «199/201»

DOI: $10.31470 / 2518-7600-2019-8-367-371$

REVIEW OF THE MONOGRAPH

BY V. KOTSURA «NATIONAL MINORITIES OF UKRAINE IN THE CONTEXT OF SOCIO-POLITICAL TRANSFORMATIONS OF 1990'S OF 20 CENTURY -

BEGINNING OF 21 CENTURY»: MONOGRAPH. PEREIASLAV- KHMELNYTSKYI, (KYIV REGION.): DOMBROVSKA Y.M., 2019.

\title{
РЕЦЕНЗІЯ НА МОНОГРАФІЮ
}

КОЦУРА В.В. НАЦІОНАЛЬНІ МЕНШИНИ УКРАЇНИ В КОНТЕКСТІ СУСПІЛЬНО-ПОЛІТИЧНИХ ТРАНСФОРМАЦІЙ 90-Х РР. ХХ СТ. - ПОЧ. ХХІ СТ.: МОНОГРАФІЯ. ПЕРЕЯСЛАВ-ХМЕЛЬНИЦЬКИЙ: ДОМБРОВСЬКА Я.М., 2019.

\section{РЕЦЕНЗИЯ НА МОНОГРАФИЮ}

КОЦУРА В.В. НАЦИОНАЛЬНЫЕ МЕНЫШИНСТВА УКРАИНЫ В КОНТЕКСТЕ ОБЩЕСТВЕННОПОЛИТИЧЕСКИХ ТРАНСФОРМАЦИЙ 90-Х ГГ. ХХ СТ. - НАЧ. ХХ В .: МОНОГРАФИЯ. ПЕРЕЯСЛАВХМЕЛЬНИЦКИЙ: ДОМБРОВСКАЯ Я.М., 2019.

Віктор Даниленко, доктор історичних наук професор, член-кореспондент НАН України, завідувач відділу історії України другої половини XX століття shln_2010@ukr.net Інституту історії України НАН України, вул. Грушевського 4, м. Київ, Україна, 01001
Victor Danilenko,

Doctor of Sciences in History, Professor, member of the National Academy of Sciences of Ukraine, Head of the Department of History of Ukraine second half of XX century

shln_2010@ukr.net Institute of History of Ukraine of National Academy of Sciences of Ukraine 01001, Ukraine, Kyiv, Grushevskogo 4 st. 
В умовах розбудови української державності особливої ваги набуває зміцнення іiі наукового потенціалу та формування кваліфікованих професійних кадрів. Подальший розвиток України в сучасних умовах пов'язаний 3 орієнтацією на метамодерні тенденції суспільного відтворення.

Суть цих тенденцій - дедалі зростаюче використання інформації і знань, як найважливішого виду ресурсів, який все більшою мірою визначає майбутнє держави. Водночас у сучасному світі не пропонується певної «правильної» одиничної чи плюралістичної позиції, натомість стверджується, що іiі слід шукати особисто і лишатися в стані пошуку між протилежностями. У даному ракурсі актуальним виявляється авторський погляд В.В. Коцура на проблематику національних меншин України 90-х рр. XX ст. - поч. XXI ст. Дослідником поглиблюється думка, яка активно обговорюється в сучасному інтелектуальному просторі, про роль суспільно-політичних трансформацій та їх вплив на статус українців, інших етнічних спільнот в Україні, формування громадянської ідентичності поліетнічного населення держави. Підтвердженням цієї думки слугують прорахунки російського агресора щодо розколу українського суспільства за національною ознакою, на що робилася ставка сусідньої держави напередодні неоголошеної російсько-української війни.

Автором подається сучасне бачення духовноінтелектуальної ситуації, що склалася в багатонаціональному українському соціумі, появи нових суджень щодо державного регулювання процесів політизації етнічності в Україні у відповідь на зовнішньополітичні виклики XXI ст.

Висвітлення проблематики національних меншини України в контексті суспільно-політичних трансформацій 90-х pp. XX ст. - поч. XXI ст. обумовлена насамперед потребою критичного переосмислення пройдених етапів розвитку, уникаючи помилок минулого заради майбутнього. У цьому плані монографія В.В. Коцура є актуальною і дає відповіді на низку питань, зумовлених викликами XXI століття в царині міжнаціональних відносин.

У структурі монографії сім розділів та додатки, в яких послідовно висвітлюються різні аспекти суспільно- 
політичного, соціокультурного життя національних меншин України на тлі трансформаційних процесів 90-х рр. XX ст. - поч. XXI ст.

Автором грунтовно проаналізовано стан наукової розробки проблеми, концептуальні підходи B історіографічному дискурсі, на основі широкого кола джерел простежено процес нагромадження і поширення в просторовочасовому вимірі історичних знань щодо місця $\mathrm{i}$ ролі національних меншин у соціокультурному i політичному просторі незалежної Української держави.

У першому розділі автор зосереджується на дослідницькій рефлексії, інтерпретації і власному баченні актуальної проблематики національних меншин 90-х рр. XX ст. - поч. XXI ст. Відслідковуються здобутки і характерні погляди вітчизняних і зарубіжних дослідників в осмисленні проблематики національних меншин, особливо їх впливу їх впливу на становлення державної етнонаціональної політики, формування нормативно-правової бази міжнаціональних відносин незалежної Української держави та структуризацію державного регулювання етнонаціональних відносин. Усі ці питання дослідник розглядає в контексті зовнішньополітичних викликів першої половини 1990 - х рр.

Етнополітичні процеси в України другої полонини 1990x pp., їх провідні тенденції та складники розвитку розглянуто у третьому розділі. Особливу увагу дослідник концентрує на виявленні визначальних чинників етнополітичних відносин в Україні другої половини 1990-х рр., імплементації міжнародних угод в сфері регулювання міжнаціональних відносин. Етнополітичний простір України автор характеризує в ракурсі неоімперських впливів Російської Федерації, втручання їі у внутрішнє життя суверенної держави.

Особливостям етнонаціональних процесів в Україні на початку XXI століття, аналізу нормативно-правової бази етнонаціональнальних відносин в України присвячується четвертий розділ. Тут відслідковується ставлення національних меншин до «Помаранчевої революції» 2004 р., перебіг подій суспільно-політичного життя початку XXI ст. 
У п’ятому розділі національні меншини України розглядаються в динаміці суспільно-політичного життя 20042010 рр. під кутом зору суспільних очікувань від реалізацій ідей-стратегій «помаранчевої» команди та нереалізованих проектів, нових зовнішньополітичних викликів.

Характерні етнополітичні чинники соціальноекономічного життя в Україні напередодні російсько-української війни (2010-2014 рр.) висвітлюються автором у шостому розділі монографічного дослідження. Дослідник відслідковує трансформації нормативно-правової бази міжнаціональних відносин в Україні 2010-2014 pp., державного регулювання під впливом зовнішньополітичних чинників початку нового тисячоліття.

Сьомий розділ присвячений етнополітичним процесам в Україні в умовах неоголошеної російсько-української війни. Чільне місце відводилося проблематиці «гібридної війни» і зовнішньополітичних впливів на національні меншини в Україні.

Отже, автор спробував розкрити багатогранну проблематику національних меншин України на тлі соціальнополітичних трансформацій на зламі століть, в умовах геополітичних викликів, а саме: російської агресії, гібридної війни, насаджування в інформаційному просторі ідей «русского мира». Положення й висновки монографічного дослідження мають певні практичні виміри і можуть бути використані в освітньо-науковій роботі вищої школи. У роботі побіжно автором з'ясовуються окремі дефініції: «національні меншини», «етнополітика», «етнічні спільноти», «російськоукраїнська війна», «гібридна війна», «русский мир», «зовнішньополітичний вплив», «геополітика», «захист прав соотечественников» тощо. Проте, на нашу думку, дані поняття потребують більш глибшої текстуальної характеристики під кутом зору сучасного наукового дискурсу. Повнішої акцентуації потребують соціально-економічні аспекти діяльності національних меншин в умовах трансформаційних процесів в Україні 90-х рр. XX ст. та глобальних змін на початку XXI ст.

В цілому творча пошукова, аналітико-критична робота, проведена дослідником, заслуговує на позитивну оцінку 3 
огляду на їі актуальність і соціальний запит. До цього слід додати і окреслені В.В. Коцуром у висновках перспективні теми подальших наукових розвідок у царині суспільнополітичного життя національних меншин. Йдеться насамперед про розробку проблематики національних меншин в Україні 90-х pp. XX ст. - поч. XXI ст. як за галузевим, так i регіональним принципами. Автору вдалося досягнути дослідницької мети, а тому монографія буде корисною не лише для вузького кола фахівців, але й для усіх, хто цікавиться історією України, проблемами міжетнічних відносин в умовах глобалізації, коли стираються географічні кордони соціальних, економічних і культурних систем, посилюється взаємозалежність світу. 